\section{The Importance of School Gardens as Perceived by Florida Elementary School Teachers}

\author{
Sonja M. Skelly and \\ Jennifer C. Bradley²
}

AdDITIONAL INDEX WORDS. Elementary education, gardening, children, experiential learning, environmental education.

Summary. While gardening is the number one hobby in the U nited States, elementary schools are just beginning to explore the use of school gardens as a means to enhance classroom learning. School gardens can reinforce classroom instruction by offering opportunities for experiential learning. The benefits of experiential learning allow for a better understanding of concepts as the hands-on approach provides meaningful and tangible experiences. While many teachers have anecdotally attested to

D epartment of Environmental $\mathrm{H}$ orticulture, $\mathrm{U}$ niversity of Florida, Gainesville, FL 32611-0670.

Contribution as J ournal Series Paper no. R-06783 of the Florida Agricultural Experiment Station. The cost of publishing this paper was defrayed in part by the payment of page charges. U nder postal regulations, this paper therefore must be hereby marked advertise ment solely to indicate this fact.

${ }^{1}$ Research assistant.

${ }^{2}$ Assistant professor. the benefits of school gardens, there is little empirical evidence documenting their impact. In Fall 1997, the U niversity of Florida hosted a competition for the best elementary school garden in Florida. R esults from a research questionnaire completed by participating teachers indicated that teachers used school gardens infrequently, with the majority using the garden as an instructional tool no more than $10 \%$ of the time. $M$ any teachers did, however, indicate that school gardens were used for environmental education (97.1\%) and experiential learning (72.9\%), and $84.3 \%$ of teachers said that related activities enhanced student learning. Findings also indicate that the teachers surveyed had relatively new gardens and teachers lacked, or were unaware of educational resources to assist with garden learning. This paper describes and interprets the results of the teacher questionnaire.

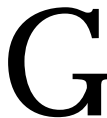

ardening is the most popular hobby in the U nited States, with an industry worth $\$ 22$ billion annually (Peyser and Weingarten, 1998). While the general public has embraced gardening for years, A merica's schoolsare just beginning to do the same. School gardensprovidea hands-on learning environment that may help improve the understanding of subjects taught using traditional classroom instruction (Barron, 1993; Bradley and Skelly, 1997; Bowen, 1989; Canaris, 1995; Kutsumai, 1994; O cone and Pranis, 1983). Gardening can facilitate student interaction with teachers, parents, and volunteers, primarilythrough growing plants and discovering the relationships between people, plants and wildlife (Alexander et al., 1995). The school garden may also serve as a resource to teach science-related subjects and allow students to learn in an environment quite unlike established classrooms. Additionally, a school garden, if used properly can be a tool to teach a multitude of subjects ranging from traditional science, to math, history, art and language arts (EamesSheavly, 1994). School gardens can also promote active and experiential learning through lessons and activities that aretaught with the garden ( $M$ abie and Baker, 1996). Studies have shown that active and experiential learning enhances students' knowledge levels (M cCormick et al., 1989; M eichtry, 1992; H arvey, 1989). Through handson learning and active participation in the learning process that students may experience in a school garden, students' learning may become more meaningful. While there is anecdotal support that praises the merits and the benefits of a school garden for students (Barron, 1993; Bowen, 1989; Canaris, 1995; Kutsumai, 1994), little research has been conducted to determine the benefits of school gardens to students. This paper is intended to address the perceptions teachers have of school gardens and the role these perceptions play in the use and success of school gardens.

In Fall 1997, researchers at the U niversity of Florida (UF) hosted a school garden competition. The goal of the competition wasto promotethe use of school gardens and reward schools that had outstanding school gardens. R esearchersat U F conducted a research study with participating schoolsto explorethe benefits of school gardens to students.

\section{Materials and methods}

In 1997, 35 schools, including 71 teachers, entered the competition and agreed to participate in the study. Teachers from participating schools were asked to voluntarily complete an anonymous questionnaire about their garden programs to bereturned to U F at the end of their school term. The questionnaire, written by the authors, contained 18 close-ended and partially close-ended questions. Q uestions surveyed the amount of time students spent in the garden, the amount of time the garden was used as a classroom tool, the type of garden, and other questions relating to the garden program. The questionnaire was designed to gain an understanding of the 
importance of school gardensand how they were being used at participating schools. The data were analyzed with SPSS (Statistical Package for the Social Sciences, 1999). D escriptive statistics, including frequencies and percentages were computed for each question on the questionnaire to determine data trends.

\section{Results and discussion}

Seventy-one Florida elementary school teachers representing schools throughout the state completed the questionnaires. The most common gardens used in schools were flower gardens (84.3\%) and vegetable gardens (71.4\%), with additional popular garden types including butterfly and herb gardens (Table 1). Follow-up interviewswith several teachersrevealed that some schools were using vegetable and butterfly gardens to supplement science lessons while flower gardens were being used to enhance their schoolyard or classroom building.

The majority of the teachers $(67.6 \%)$ indicated that their students spent an average of 1 hour in the garden per week (Table 1 ). The remaining teachers $(16.9 \%)$ indicated that their students spent 2 to 3 hours in the garden and $15.4 \%$ of teachers indicated that their students spent between 4 and $8 \mathrm{~h}$ in the garden each week. These results indicate that while the participating schoolsmay havegardens, most were not being used very often. A large percentage of teachers $(60.5 \%)$ indicated that the garden was being used as an instructional tool either $10 \%$ or less than $10 \%$ of the time
(Table 1 ). While $39.4 \%$ of teachers indicated that the garden was used at least $20 \%$ of the time as an instructional tool, most teachers indicated that they were using the garden minimally. T eachers may not have, or were unaware of availableresources (E amesSheavly, 1993; J affe and A ppel, 1990; $O$ cone and Pranis, 1983; Skelly and Zajicek, 1997; Waliczek and Zajicek, 1996) on incorporating gardens into existing lessons and, hence, failed to effectively use the garden as a teaching tool. Furthermore, Spooner and Simpson (1979) reported that neutral or negative attitudes towards science itself might be why elementary school teachers tend to teach little or no science, leaving little opportunity for using the garden as a tool to teach science.

T able 1. R esults of a school garden questionnaire completed by Florida elementary school teachers.

Q uestion

Type of garden at school

Flower

Vegetable

Butterfly

$\mathrm{H}$ erb

Amount of time students spend in garden (hours per week)

1

$2-3$

4-5

$6-7$

7-8

O ther

Amount of time the garden is used by teachers in the classroom

$<10 \%$

$10 \%$

$20 \%$

$30 \%$

$40 \%$

$50 \%+$

Reasons teachers use a school garden

Environmental education

$\mathrm{H}$ elps students learn better

Experiential learning

Personal love of gardening

Encouraged by the administration

$\mathrm{N}$ umber of years the garden had been established at the school

6 months or less

$1-1.5$

$2-3$

$4^{+}$

Sources of school garden funding

Donations

Personal funds

Garden grants

School funds
Percentage ${ }^{z}$

( $\mathrm{N}=71$ ) 
When asked what the garden was used for, all but two of the teachers $(97.1 \%)$ indicated that they used the garden for environmental education and $72.9 \%$ indicated that the garden was used for experiential learning (Table 1). Eighty-four percent of the teachers felt that the garden helped students learn better.

Perhaps one of the most important reasons that the teachers surveyed were not using school gardens very often was the length of time the garden had been established. A largenumber (42.2\%) of school gardensused by teachers in this study had been established for 6 months or less, with $69 \%$ of the gardens in establishment less than a year and a half ( $T$ able 1 ). With many of the gardens being established and put to use for a year or less, teachers may not have had the opportunity to use and incorporate the garden into their classroom instruction. Additionally, teachers may not yet have been comfortable with this teaching technique.

Several explanations exist as to why more teachers did not use school gardens. 0 ne explanation may be that teachers were unaware of how to successfully incorporate the garden into an already existing curriculum to enhance student learning. Another explanation comes from the expense of a garden. Teachers in this study indicated that they received donations (69.9\%), grants $(49.3 \%)$, and even paid for the garden with their own money (52.1\%) (Table 1 ). Teachers noted that many of the donations came from parents as well as local garden centers. While close to half $(49.3 \%)$ the teachers had received a garden grant, most of those not receiving a grant were unaware that such grant funding existed. Funding a school garden can become an expensive task and may discourage many teachersfrom using a garden.

\section{Conclusions}

Responses from a 1998 survey given to 71 Florida elementary school teachers indicated that school gardens are gaining popularity as a resource for educating children. Findings reveal that, for this group of teachers, gardens were used minimally for classroom instruction. H owever, thelength of time these gardens had been established was also minimal, with most gardens in establishment less than a year and a half. The reasons cited most often for incorporating a garden into the curriculum was for environmental education and for fostering experiential learning. While some of the results of this survey may seem discouraging to proponents of school gardening, it is important to note that, regardless of the time spent in the garden, teachers are using school gardens. I t is apparent from findings in this study that teachers need to be made aware of the resources available to help them effectively integrate the garden into more classroom lessons. I ntegrating thegarden and garden activities into classroom lessons will not only enable the teacher and the students to use the garden more, but may also enhance students' learning. It is apparent that many teachers understand the usefulness of the garden and the impact it may have on student learning. This finding helps support the belief that elementary school gardens are valuable, conceivably indicating that educatorsare beginning to understand the benefits of gardening to children.

\section{Literature cited}

Alexander, J., M.W. N orth, and D. $\mathrm{H}$ endren. 1995. M aster gardener classroom garden project: An evaluation of the benefits to children. Child. Environ. 12(2):256-263.

Barron, J. 1993. The greening of St. Patrick's. pathways. 0 nt. J . O utdoor Educ. 5(4):5-7.

Bowen, D. 1989. Gardens of knowledge. Sci. Teach. 56(5):53-55.

Bradley, J.C. and S.M. Skelly. 1997. Children and gardening-Implications for the future. Proc. Fla. StateH ort. Soc. 110:405407.

Canaris, I. 1995. Growing foodsfor growing minds: Integrating gardening and nutrition education into the total curriculum. Child. Environ. 12(2):264-270.
Eames-Sheavly, M . 1994. Exploring horticulture in human culture: An interdisciplinary approach to youth education. $\mathrm{H}$ ortTechnology 4(1):77-80.

Eames-Sheavly, M. 1993. The three sisters: exploring an I roquoisgarden. Cornell Coop. Ext., I thaca, N.Y.

$\mathrm{H}$ arvey, M. 1989. The relationship between children's experiences with vegetation on school grounds and their environmental attitudes. J. Environ. Educ. 21(2):915.

Jaffe, R. and G. Appel. 1990. The growing classroom. Addison-Wesley Publ. Co., Menlo, Calif.

Kutsunai, B. 1994. O ur garden is a growing place. Kamehameha J. Educ. 5:1-10.

M abie, R. and M . Baker. 1996. The influence of experiential instruction on urban elementary students' knowledge of the food and fiber system. J. Ext. 34(6):1-4.

M cCormick, F.G., D.E. Cox, and G.M. M iller. 1989. Experiential needs of students in agricultural programs. Agr. Educ. Mag. 62(4):10-1.

M eichtry, Y.J . 1992. U sing laboratory experiences to develop the scientific literacy of middle school students. School Sci. $M$ ath. 92(8):437-441.

O cone, L. and E. Pranis. 1983. The $\mathrm{Na}$ tional Gardening Association's guide to kid'sgardening. WileySci. E ds., N ew York.

Peyser, M. and T. Weingarten. 1998. A growing experience: Spring is here and children'sgardensarein bloom. N ewsweek 4/ 13/ 98:65.

Skelly, S. and J. Zajicek. 1997. Project Green book 2: Interdisciplinary activities. Texas A\& M U niv. I nstructional M aterial Serv., College Station.

Spooner, W.E. and R.D. Simpson. 1979. The influence of a five day workshop on attending elementary teachers toward scienceand scienceteaching. School Sci. M ath. 70(3):415-420.

Statistical Package for the Social Sciences. 1999. Statistical package for the social sciences 9.0 for W indows. SPSS I nc., Chicago.

Waliczek, T. and J. Zajicek. 1996. Project Green book 1: Science and math. Texas A\& M U niv. Instructional M aterial Serv., College Station. 